\title{
Coexistent Felty's syndrome and palindromic rheumatism
}

\author{
Ricardo E Alvillar, Lois O'Grady, Dick Robbins
}

\begin{abstract}
Palindromic rheumatism is a syndrome of intermittent abrupt onset monoarthritis with asymptomatic intercritical periods of variable duration, which commonly evolves into rheumatoid arthritis. Felty's syndrome consists of leucopenia (selective neutropenia) and splenomegaly, usually occurring in longstanding classic rheumatoid arthritis. Felty's syndrome can be confused with the more recently recognised rheumatoid arthritis associated large granular lymphocyte proliferative disease. This paper describes a patient with palindromic rheumatism presenting with Felty's syndrome in whom large granular lymphocyte proliferative disease was ruled out by lymphocyte phenotyping.
\end{abstract}

Palindromic rheumatism, first described in 1941 by Hench and Rosenberg, ${ }^{1}$ refers to a syndrome of monoarticular joint pain that characteristically begins abruptly, reaches its peak within hours, and subsides within one to three days followed by an asymptomatic intercritical period of variable duration. About $30-50 \%$ of these patients may develop rheumatoid arthritis, especially if they carry the HLA-DR4 haplotype ${ }^{2}$ and have positive serology.

Felty described five patients with the triad of chronic arthritis, splenomegaly, and leucopenia. ${ }^{3}$ Patients almost always develop Felty's syndrome after at least two years of chronic seropositive rheumatoid arthritis. The prevalence of Felty's syndrome is probably less than $1 \%$ of patients with rheumatoid arthritis, and the prevalence of the HLA-DR4 haplotype in patients with Felty's syndrome is $95 \%$. Only one example of palindromic rheumatism and Felty's syndrome has been reported. ${ }^{4}$

More recently, large granular lymphocyte proliferative disease has been reported to be associated with rheumatoid arthritis. Large granular lymphocyte proliferative disease is a relatively rare atypical lymphocytosis characterised by azurophilic cytoplasmic granules. As neutropenia and splenomegaly are prominent

Initial laboratory features of patient

\begin{tabular}{lllllll}
\hline $\begin{array}{l}\text { White blood cell } \\
\text { count and } \\
\text { differential }\end{array}$ & $\begin{array}{l}\text { Haemoglobin } \\
(\mathrm{g} / \mathrm{l})\end{array}$ & $\begin{array}{l}\text { Platelets } \\
\left(\times 10^{9} / \mathrm{l}\right)\end{array}$ & $\begin{array}{l}\text { Erythocyte } \\
\text { sedimentation } \\
\text { rate } \\
(\mathrm{mm} / \mathrm{h})\end{array}$ & $\begin{array}{l}\text { Rheumatoid } \\
\text { factor }\end{array}$ & Peripheral smear & Bone marrow \\
\hline $\begin{array}{l}1 \cdot 9 \times 10^{9} / \text { litre } \\
2 \text { Polymorphonuclear } \\
\text { cells }\end{array}$ & 136 & 249 & 10 & $1 / 40$ & $\begin{array}{l}\text { Occasional large } \\
\text { lymphocytes, } \\
\text { neutropenia, normal } \\
\text { red blood cells and } \\
\text { platelets }\end{array}$ & $\begin{array}{c}\text { Maturation arrest at } \\
\text { metamyelocyte stage } \\
\text { without more mature } \\
\text { forms. No lymphocytic } \\
\text { infiltration }\end{array}$ \\
$\begin{array}{l}\text { 1 Band } \\
\text { 17 Lymphocytes }\end{array}$ & & & & & & \\
16 Mosinophils & & & & & & \\
\hline
\end{tabular}

features of large granular lymphocyte proliferative disease, it has been mistaken for Felty's syndrome. ${ }^{5}$ Linch et al first compared the two diseases and noted that cell surface markers could distinguish between them. The prognosis of patients with large granular lymphocyte proliferative disease appears to be better than that associated with Felty's syndrome ${ }^{7}{ }^{8}$; the treatment is the same for either condition when large granular lymphocyte proliferative disease is associated with rheumatoid arthritis.

\section{Case report}

A 50 year old white male truck driver was referred to us by his haematologist to evaluate prednisone resistant neutropenia, splenomegaly, and synovitis of the right elbow and wrist.

Further evaluation showed a history consistent with palindromic rheumatism and characterised by up to 100 attacks per year over the past 10 years. These attacks had an explosive onset of monoarticular pain, swelling, and warmth that subsided completely 48-72 hours later, only to recur in a different joint, in a migratory fashion. Occasionally, only pain without swelling was present. The measurement of rheumatoid factor was positive in a titre of $1 / 640$ during one episode of active arthritis. Subsequent rheumatoid factor titres were 1/40 between attacks. In September 1988 the patient underwent preoperative evaluation for haemorrhoidectomy and was found to be leucopenic. His haematologist advised him to stop taking butriptyline and indomethacin (his only drug treatment to that point) and took a bone marrow biopsy specimen and peripheral smear (see table). The patient was given a course of steroids (prednisone $80 \mathrm{mg} / \mathrm{d}$ ) which gave no improvement in his leucopenia. He underwent a liver-spleen scan and computed tomography which showed a spleen four times the normal size. He was referred to us for an evaluation to determine whether he had Felty's syndrome.

In examination the patient had normal vital signs. Pertinent findings included active synovitis of the right wrist and elbow; the rest of his

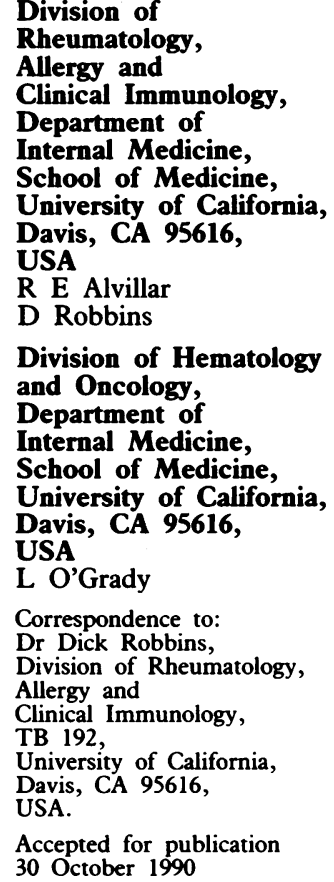

School of Medicine University of California, Davis, CA 95616 USA

L O'Grady

Correspondence to:

Dr Dick Robbins,

Division of Rheumatology,

Allergy and

Clinical Immunology

TB 192

University of California

Davis, CA 95616

USA.

Accepted for publication

30 October 1990 
joints were normal. An abdominal examination disclosed an enlarged, soft spleen. The pertinent laboratory findings are summarised in the table. A review of the peripheral smear by our haematologist showed some large granular lymphocytes, neutropenia, normal platelets, and red cells. Electrophoresis of serum protein gave normal results. Antineutrophil antibodies could not be demonstrated. The patient typed positive for HLA-DR4 and HLA-DRw6. A radiograph of his hands, wrists, elbows, and feet showed no erosion.

Three months later the patient developed symmetric synovitis of the wrists, elbows, and ankles. Nodules were palpable over the extensor forearm bilaterally. He was given a trial of methotrexate $7.5 \mathrm{mg} /$ week for one month. Eight weeks after he had stopped the methotrexate he underwent lymphocyte phenotyping but refused a repeat bone marrow examination. Lymphocyte phenotyping was normal. Methotrexate was begun again and three months later there was no evidence of active synovitis and his white blood cell count was $7 \cdot 7 \times 10^{9} / 1$ with $60 \%$ granulocytes and $32 \%$ lymphocytes.

\section{Discussion}

We presented this case to compare palindromic rheumatism, Felty's syndrome, and the more recently described large granular lymphocyte proliferative disease and to describe our approach in differentiating Felty's syndrome from large granular lymphocyte proliferative disease in patients with rheumatoid arthritis.

Palindromic rheumatism classically ${ }^{1}$ affects men almost as frequently as women, has a wide age range at onset but with most occurring in the second and third decades, and may evolve into rheumatoid arthritis after several years or may continue for 20 or more years without disabling the patient. Attacks usually involve one joint, but as many as three joints may be affected. The attacks usually occur with an explosive onset of arthritis or periarthritis, which subsides within one to three days, although they may last as long as one week or as briefly as a few hours. The intercritical periods last from hours to months. The joints most commonly affected include the fingers, wrists, shoulders, knees, toes, or elbows; however, almost any joint, including temperomandibular and sternoclavicular joints, may be affected. Subcutaneous nodules, identical to rheumatoid nodules on pathological examination, may be found, usually on the fingerpads. Constitutional symptoms are uncommon.

Laboratory, $x$ ray and pathological studies in palindromic rheumatism ${ }^{2}$ are generally normal or unrevealing. The synovial fluid shows neutrophilia during an attack, but no crystals or bacteria. Some changes characteristic of rheumatoid arthritis may be found in synovial biopsy samples. Treatment includes gold, Dpenicillamine or antimalarial drugs. ${ }^{9}$ The prognosis for patients who never develop rheumatoid arthritis is good.

Felty's syndrome classically consists of chronic rheumatoid arthritis with splenomegaly and leucopenia (neutropenia). ${ }^{3}$ The mechanism of neutropenia remains elusive: popular hypotheses include splenic sequestration of granulocytes loaded with immune complexes, ${ }^{10}$ decreased neutrophil survival secondary to antibodies on cell surface receptors, ${ }^{11}$ and margination of neutrophils. ${ }^{11} \mathrm{~A}$ circulating inhibitor or direct inhibition of granulopoiesis by mononuclear cells has also been proposed. ${ }^{11}$ The spleen is enlarged in about $90 \%$ of patients and extraarticular features of rheumatoid arthritis are common. About $60 \%$ of patients develop infections, usually staphylococcus, streptococcus, and Gram negative rods. Despite the neutropenia, pus accumulates in the usual manner. The bone marrow may be normal but myeloid hyperplasia with 'maturation arrest' (impaired myelopoietic response $v$ early release of mature forms) is usually present. Ninety five per cent of patients with Felty's syndrome have HLADR4, compared with $69 \%$ of patients with rheumatoid arthritis and $31 \%$ of control patients. Rheumatoid factor is present in $98 \%$ of patients, usually in high titre. Lupus erythematosus cells and positive antinuclear antibodies are found in $47-100 \%$ (usually two thirds of patients); granulocyte specific antinuclear antibodies may be found in $85 \%$ of patients with Felty's syndrome $v 14 \%$ of patients with rheumatoid arthritis who have normal white blood cell counts. Treatment includes gold, D-penicillamine, or methotrexate, all of which may improve granulocytopenia as well as treating the underlying rheumatoid arthritis. High doses of parenteral testosterone and lithium are also non-surgical treatments. Splenectomy may have a dramatic, but short lived, effect. The response of this patient's white blood cell count to methotrexate is consistent with previously reported cases. ${ }^{12}$

Large granular lymphocyte proliferative disease is probably a spectrum of rare disorders, ${ }^{8} 13$ ranging from chronic, stable lymphocytosis associated with various cytopenias to an aggressive leukaemia. The lymphocytes exhibit characteristics of stimulated cells with azurophilic granules on peripheral blood smears. These cells have been seen in small numbers on normal smears. Large granular lympocytes mark for certain receptors, which suggests that they are suppressor/cytotoxic $\mathrm{T}$ cells or natural killer cells. However, their exact lineage is still not clear. The cause of large granular lymphocyte proliferative disease is also unclear. A neoplastic origin is suggested by chromosomal abnormalities in some patients but a well documented spontaneous regression suggests a disorder of immune regulation or chronic reaction. ${ }^{14}$ The demonstration of $\mathrm{T}$ cell receptor gene rearrangements ${ }^{15} 16$ may provide an answer. Further studies are necessary to determine whether large granular lymphocyte proliferative disease is a disorder of immune regulation-that is, a clonal response to a specific antigen, or leukaemic proliferation. ${ }^{8}$ If it is the latter, it should be asked whether it could have arisen from the former and, if so, how?

Clinically, large granular lymphocyte proliferative disease is characterised by moderate blood and bone marrow lymphocytosis without lymphadenopathy and usually manifests spleno- 
megaly and hypergammaglobulinaemia. Neutropenia is severe and may be complicated by infection. ${ }^{14}$ The cause of the neutropenia is unclear. ${ }^{17}$ The disease is prolonged with little progression of symptoms. The association of large granular lymphocyte proliferative disease with rheumatoid arthritis mimicking Felty's syndrome was first distinguished by Linch et $a l .{ }^{6}$ When associated with rheumatoid arthritis, large granular lymphocyte proliferative disease is commonly present at the onset of rheumatoid arthritis. The use of monoclonal antibodies by Linch $e t a t^{6}$ to separate these entities was confirmed by other workers. ${ }^{7} 1819$ Among patients with rheumatoid arthritis and neutropenia, 30-50\% may have large granular lymphocyte proliferative disease ${ }^{519}$ Bassan et $a l^{20}$ suggested that $B$ cell dysfunction may result from large granular lymphocyte proliferative disease.

The authors thank Nikki Rojo for excellent secretarial assistance, Jay J Chen, MD, for case referral, and Joel Wagner, Pharm D, for identification of the drugs from Mexico. Supported in part by grants from the AMA-ERF and the WCREF.

1 Hench P S, Rosenberg E F. Palindromic rheumatism: new oft-recurring disease of joints (arthritis, periarthritis, paraarthritis) apparently producing no articular residues; report of 34 cases. Mayo Clin Proc 1941; 16: 808.

2 Harris E D. In: Kelly W N, Harris E D, Ruddy S, Sledge C B eds. Textbook of rheumatology. Phildelphia: Saunders, 1989: 948 .

3 Felty $A$. Chronic arthritis in the adult, associated with splenomegaly and leukopenia. Fohns Hopkins Hospital splenomegaly and leu

4 Davies P G, Thompson P W. Palindromic rheumatism and Felty's syndrome. Ann Rheum Dis 1985; 44: 640-1.

5 Saway A P, Prasthofer E F, Barton J C. Prevalence of granular lymphocyte proliferation in patients with rheumatold arthritis and neutropenia. Am f Med 1989; 86: 303-7.

6 Linch D C, Newland A C, Turnbull A L, Knott L J, MacWhannel A, Beverley P. Unusual T cell proliferations and neutropenia in rheumatoid arthritis: comparison with and neutropenia in rheumatoid arthritis: comparison with classical

7 Barton J C, Prasthofer E F, Egan M L, Heck L W Jr, Koopman W J, Grossi C E. Rheumatoid arthritis associated with expanded populations of granular lymphocytes. Ann Intern Med 1986; 104: 314-23.

8 Pandolfi F, Loughran T P, Starkebaum G, et al. Clinical course and prognosis of the lymphoproliferative disease of granular lymphocytes. Cancer 1990; 65: 341-8.

9 Hardo H G. Palindromic rheumatism: a review. $\mathcal{R}$ Soc Med 1981; 74: $521-4$.

10 Hurd E R. Presence of leukocyte inclusions in spleen and bone marrow of patients with Felty's syndrome $\mathcal{f}$ Rheumatol 1978; 5: 26-32.

11 Pinals R S. In: Kelly W N, Harris E D, Ruddy S, Sledge C B, eds. Textbook of rheumatology. Philadelphia: Saunders, 1989: $993-8$.

12 Fichtner J J, Miller D R, Starkebaum G. Reversal of neutropenia with methotrexate treatment in patients with Felty's syndrome. Arthritis Rheum 1989; 32: 194-201.

13 Newland A C, Catovsky D, Linch D, et al. Chronic T-cell lymphocytosis: a review of 21 cases. Br $\mathcal{F}$ Haematol 1984; 58: 433-46.

14 McKenna R W, Arthur D C, Gajl-Peczalska K J, Flynn P, Browning R D. Granulated T cell lymphocytosis with neutropenia: malignant or benign chronic lymphoproliferative disorder? Blood 1985; 66: 259-66.

15 Pelicci P G, Allavena P, Subar M, et al. T cell receptor $(\alpha, \beta$. $\gamma$ ) gene rearrangements and expression in normal and $\gamma$ ) gene rearrangements and expression in normal and Blood 1987; 70: 1500-8.

16 Freimark B, Lanier L, Phillips J, Quertermoies T, Fox R. comparison of $\mathrm{T}$ cell receptor gene rearrangements in patients with large granular T cell leuk
syndrome. F Immunol 1987; 138: 1724-9.

17 Loughran T P, Starkebaum G. Large granular lymphocytic leukemia. Medicine (Baltimore) 1987; 66: 397-405.

18 Wallis W J, Loughran T P, Kadin M E, Clark E A Starkebaum G A. Polyarthritis and neutropenia associated with circulating large granular lymphocytes. Ann Intern Med 1985; 103: 357-62.

19 Loughran T P, Starkebaum G, Kidd P, Neiman P. Clonal proliferation of large granular lymphocytes in rheumatoid proliferatis. Arthritis Rheum 1988; 31: 31-6.

20 Bassan $R$. Pronesti M, Buzzetti M; et al. Autoimmunity and B-cell dysfunction in chronic proliferative disorders of large
granular lymphocytes/natural killer cells. Cancer 1989; 63: granular 